\title{
Lithospheric flexure, uplift, and landscape evolution in south-central England
}

\author{
A. B. WATTS, W. S. MCKERROW \& E. FIELDING \\ Department of Earth Sciences, University of Oxford, Parks Road, Oxford OX1 3PR, UK \\ (e-mail: tony.watts@earth.ox.ac.uk)
}

\begin{abstract}
The high level river gravels in Oxfordshire (the Northern Drift Group), which range in age from Early Pleistocene to around $450 \mathrm{ka}$, contain pebbles that were derived from a source area to the north near Birmingham. The pebbles could not have been transported across the Upper Triassic and Lower Jurassic clay outcrops of the Midlands unless the region was at or close to sea level. The present day Cotswold escarpment ranges from 70 to $215 \mathrm{~m}$ : this uplift must therefore have occurred after deposition of the Northern Drift Group, when the drainage of the Midlands appears to have shifted from towards the Thames basin to the Bristol Channel area. It is concluded that lithospheric flexure due to the removal of $>500 \mathrm{~km}^{3}$ of soft Late Triassic and Early Jurassic clays and marls from large areas of the Midlands and their re-deposition in the Celtic Deep might account for this Late Pleistocene uplift. Uplift in the Midlands is the likely explanation for both the tilted (approximately $0.3^{\circ}$ ) plateau surface in north Oxfordshire and the change in strike of the Jurassic beds SW of Northamptonshire. Although some uplift occurred in SE England during the Early Cenozoic and Miocene, we demonstrate here that there has been significant uplift of the region in the Late Pleistocene. The tilted plateau surface in north Oxfordshire may therefore be a relatively young (i.e. post- $450 \mathrm{ka}$ ) feature related to tectonic uplift in the Midlands.
\end{abstract}

Keywords: South-Central England, uplift, landform evolution, lithosphere.

In NE England, the Mesozoic rocks dip generally towards the east whereas in the south Midlands (including Oxfordshire) the strike swings through $45^{\circ}$ to NE to SW (e.g. inset, Fig. 1). While the north-south strike may be related to extension in the North Sea, it is not obvious why the beds in the south Midlands dip towards the SE. In north Oxfordshire, the Jurassic beds consist of alternating limestones and clays, with some subsidiary sands; they dip at about $0.5^{\circ}$. The harder beds generally form NW-facing escarpments, whereas their SE slopes merge gradually below the wide clay vales excavated along the outcrops of the Oxford Clay and other softer beds. Limestones are particularly well developed in the Cotswold Hills (Fig. 1), where the Bajocian Inferior Oolite Group (Arkell 1947) thickens to form an escarpment which rises to over $300 \mathrm{~m}$. In north Oxfordshire (east of the Cotswolds), the Inferior Oolite is very thin and the main scarp is developed at Edge Hill by the Banbury Ironstone (Pleinsbachian age), which reaches an elevation of $215 \mathrm{~m}$ (Edmonds et al. 1965). To the NW of these escarpments, the Vales of Evesham and Gloucester (Fig. 1) have been excavated in thick $(1000 \mathrm{~m})$ Upper Triassic and Lower Jurassic clays and marls.

In Oxfordshire, between the river valleys of the Windrush and Cherwell, the Jurassic beds are capped by high-level $(40-100 \mathrm{~m})$ river gravels (Fig. 2a), that have been assigned to the Northern Drift Group by Bridgland (1994, p. 36) and Gibbard (1999) and to the Kesgrave Group by Whiteman \& Rose (1992). They form a succession of terraces that are still preserved in a broad area that extends from Oxfordshire to the SE coast of England. The chronology of the gravels has been established by correlation with the oxygen isotope stages of the deep-sea (Bridgland 1994, pp. 7-17; Gibbard 1999, table 12). It is now thought, for example, that the Northern Drift Group ranges in age from Early Pleistocene to oxygen isotope stage 12 at around $450 \mathrm{ka}$ (Maddy 1997). In Oxfordshire, the group is distinguished from the younger, lower gravels by the almost complete absence of limestone clasts (Arkell 1947, p. 192; Hey 1986).

The Northern Drift Group (Bridgland 1994) contains quartz and quartzite pebbles derived from the Early Triassic 'Bunter' conglomerates, now assigned to the basal parts of the Sherwood Sandstone Group (Warrington et al. 1980) that occur in the area around Birmingham (Fig. 1). They contain some quartzite and quartz clasts and only a little debris derived from local Jurassic rocks. Younger (and lower) gravels are incised into the Jurassic plateau and contain angular debris from local Jurassic rocks. Buckland (1823, p. 425) realized that (a) the pebbles in these higher terraces had originated in the Midlands, and (b) that they had been deposited by a 'deluge' before the present-day river valleys of the Windrush, Evenlode and Cherwell had been excavated. The quartz and quartzite pebbles range in size from 10 to $50 \mathrm{~cm}$ and were transported by fast flowing rivers, probably originating from the margins of an ice sheet in central England; they were rounded during their transport by Early Triassic rivers which flowed north from NW France to the English Midlands (Audley-Charles 1970; Cocks 1993). A few of the Oxfordshire pebbles are in the form of hemispheres, with sharp edges around the planar side indicating that their transport during the Pleistocene did not involve much rounding.

The Mesozoic beds of the Vales of Evesham and Gloucester consist of about $1000 \mathrm{~m}$ of marls and clays which are younger than the Early Triassic conglomerates and older than the scarp-forming Jurassic beds. Whatever the level of erosion, there is no doubt that there would have been wide outcrops of the Late Triassic and Early Jurassic sediments in the Midlands. These outcrops of easily eroded softer beds (Fig. 2b) were traversed by the fast-flowing rivers carrying the quartzite pebbles of the Northern Drift Group prior to $450 \mathrm{ka}$. If the Midlands had been much above sea level at this time, the softer beds would have been preferentially eroded and the rivers would have been diverted along their strike. The fact that 


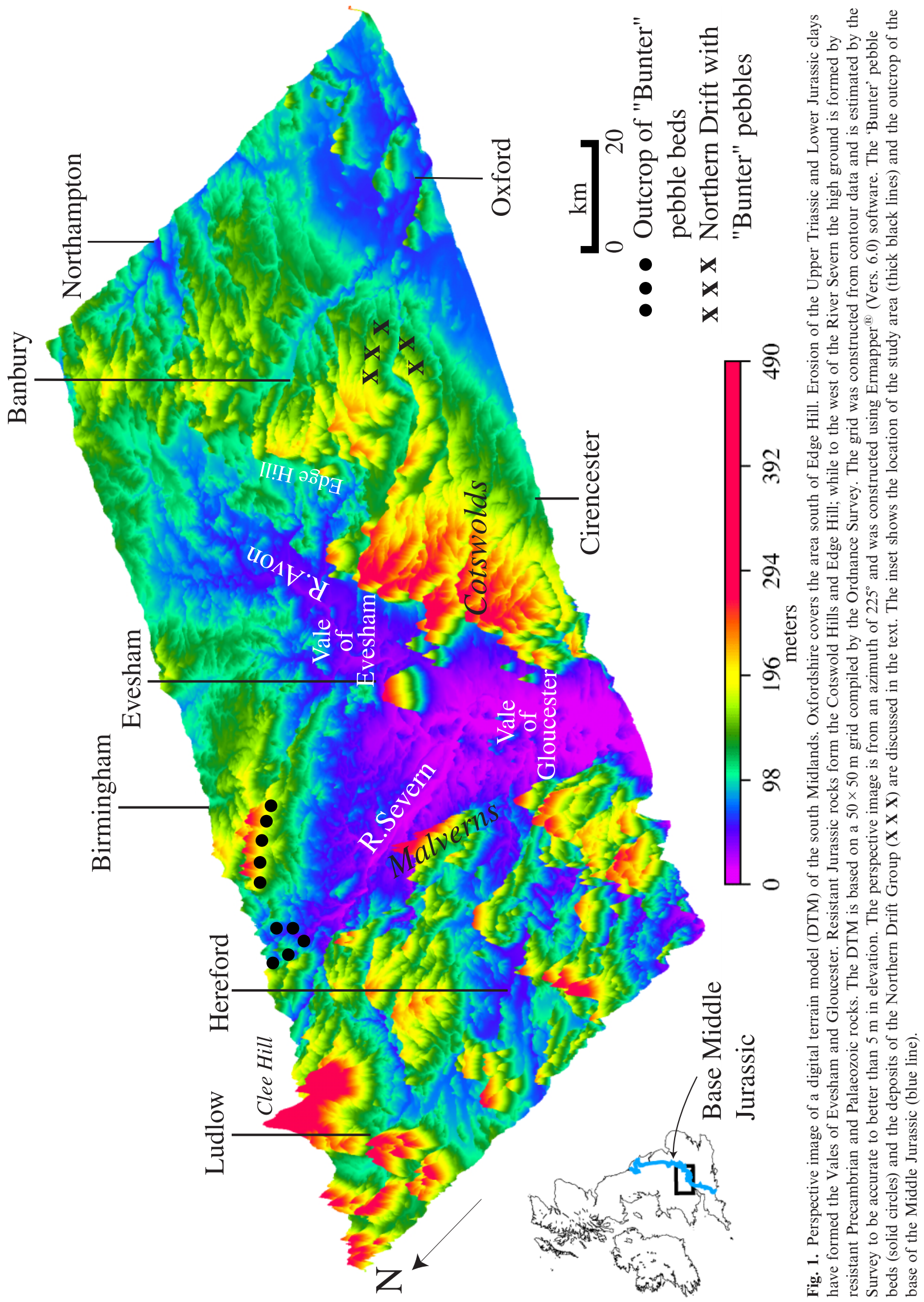




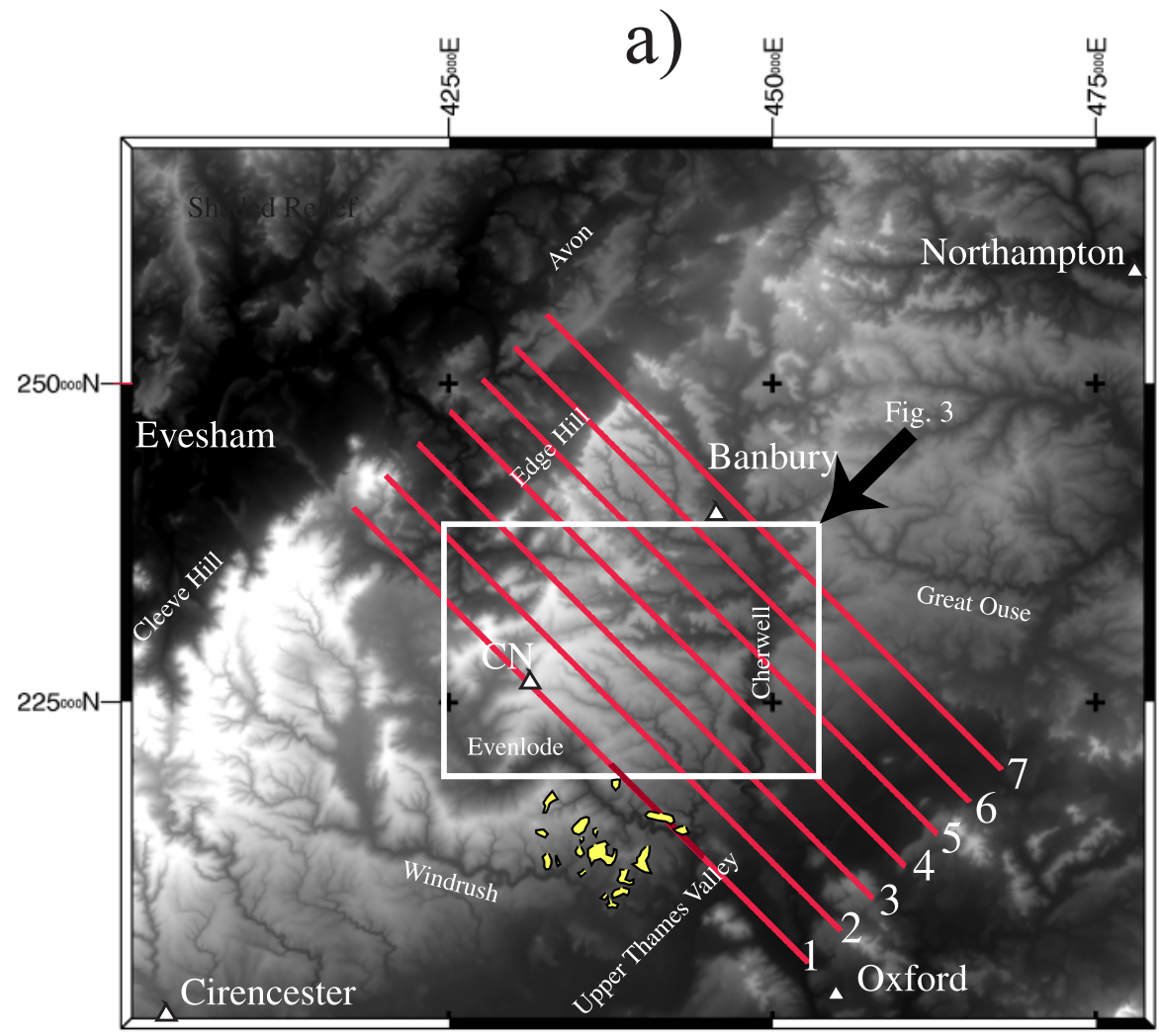

Northern Drift Group $\nabla$

\section{b)}

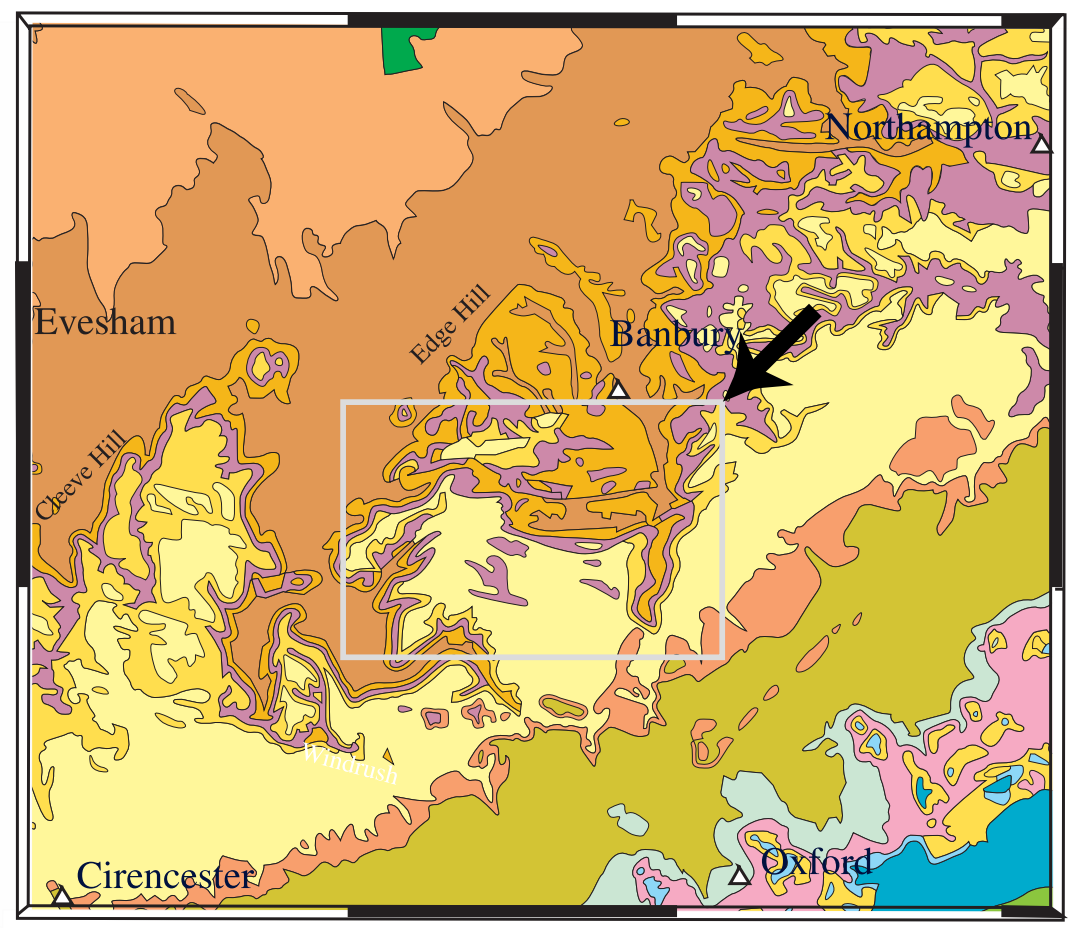

Chalk, including Red Chalk Upper Greensand and Gault Lower Greensand Kimmerridge Clay Oxford Clay and Kellaway Beds Cornbrash Great Oolite Inferior Oolite Upper Lias Middle Lias Lower Lias Triassic Mudstones Carboniferous with basal conglomerate

Fig. 2. Shaded relief and summary geological map of north Oxfordshire. (a) Shaded relief map showing the heavy dissection of the tilted plateau of north Oxfordshire by the main rivers and tributaries. Also shown is the location of the Northern Drift Group. Large type shows the location of major towns. Small type shows the location of the main rivers and tributaries. The solid lines show the location of topographic Profiles 1-7 used to construct Fig. 5. The white box shows the outline of the BGS geology map of the Chipping Norton region (Sheet 218), used to construct Fig. 3. CN is Chipping Norton. Co-ordinates are British National Grid. (b) Summary geological map showing the main formations. 
today the Oxfordshire terraces containing the Triassic pebbles from Birmingham are $>100 \mathrm{~m}$ above sea level (Hey 1986) shows that this uplift has occurred since deposition of the Northern Drift Group, that is since $450 \mathrm{ka}$. The purpose of this paper is to investigate the possible causes of this Late Pleistocene uplift.

The direction of the NE-SW trend of the Cotswold and Edge Hill escarpments are difficult to explain by either a flexural or thermal bulge due to east-west extension in the North Sea or by north-south extension in the London basin and English Channel. To the contrary, the proximity of the scarps to the Vales of Evesham and Gloucester suggest they are somehow related.

\section{The excavation of the Vales of Evesham and Gloucester}

A study of the present-day topography is essential for the complete understanding of recent crustal movements. Digital terrain models (DTMs) constructed by the Ordnance Survey from contour data show that the eastern margin of the Vales of Evesham and Gloucester are topographically well defined by the escarpments of the Cotswold and Edge Hill (Figs 1 and 2). The western margin, in contrast, is associated with a fault line between the Precambrian and Palaeozoic rocks along the eastern margin of the Malvern Hills, separating these older rocks from the thick Permian and Mesozoic of the Worcester Graben (which underlies much of the south Midlands, east of the Malvern Hills).

Quantitative estimates of the volume of soft sediment that have been removed from the Vales of Evesham and Gloucester are not easy to make. The main problem is in estimating the height of the Vale flanks. The eastern flank is demarcated along the Cotswold and Edge Hill escarpments. It is more difficult to estimate the height of the flanks to the west, where the main problem is the heavy dissection of Herefordshire (to the west of the Malvern Line) by a complex system of rivers.

We found, however, that a low-pass filter of the DTM was generally successful in suppressing the short-wavelength river valleys while enhancing the long wavelengths of the flanks. Filtered topographic maps with, for example, a taper between 20 and $60 \mathrm{~km}$ suggest that the flanks presently stand some $100-200 \mathrm{~m}$ above the floor of the Vales of Evesham and Gloucester. If we assume a mean height of $150 \mathrm{~m}$ for the flanks, then the DTMs suggest that some $500 \mathrm{~km}^{3}$ of sediments have been removed by the excavation.

If large volumes of rock have been removed from the Vales of Evesham and Gloucester during the past $450 \mathrm{ka}$, there should be evidence of contemporary deposits in surrounding regions. Today, the Severn and its tributaries drain these Vales through the Bristol Channel. Strong tidal currents in the channel, however, limit deposition to the Celtic Sea. Beneath the Celtic Sea, SW of Wales, is a bathymetric trough (the Celtic Deep) which is underlain by up to $350 \mathrm{~m}$ of fine-grained Pleistocene and younger sediments. These sediments unconformably overlie mid-Miocene and older rocks (Tappin et al. 1994). According to Tappin et al. (1994), the basal Pleistocene deposits in the Celtic Deep are of Anglian age which is strikingly close to a date of $450 \mathrm{ka}$, the youngest age of the Oxfordshire quartzites derived from around Birmingham. This similarity in ages suggests a causal connection between the excavation of the Vales of Evesham and Gloucester, the initiation of uplift on the flanks of the Severn valley, and the onset of sedimentation in the Celtic Deep.
One factor that may have controlled the excavation is the fluctuation in the amount of glacial melt water. During the Pleistocene, south-central England was subject to a number of retreats and advances of ice sheets (Bowen et al. 1987). The distribution of early Pleistocene ice sheets is quite conjectural. There is no evidence of how far south they extended. However, after the development of the Cotswold and Edge Hill escarpments in the later Pleistocene, the ice was probably confined to the north of these features (Graham \& Straw 1988, fig. Q1a). To the east, the escarpment becomes less well developed and hence the ice covered the younger Jurassic outcrops of Northamptonshire and extended as far south as St Albans in Hertfordshire.

Another factor is the structure of the rocks. Once the more resistant gently dipping rocks of the Cotswolds have been removed, the underlying softer beds are easily eroded, so the Jurassic escarpments to the east of the Vales of Evesham and Gloucester retreated through time. In contrast, the folded Precambrian and Palaeozoic rocks of the Malvern Hills and Herefordshire to the west have been governed by tectonic structures which did not migrate.

\section{Flexural unloading}

Regardless of the factors controlling the excavation, it is clear from the DTM in Fig. 1 that large volumes of sedimentary material (up to $500 \mathrm{~km}^{3}$ ) have been removed from the Vales of Evesham and Gloucester. The age of the Northern Drift Group and the Pleistocene stratigraphy of the Celtic Deep both suggest that the excavation has occurred during the past $450 \mathrm{ka}$.

We know from isostasy that the crust responds to changing load distributions on its surface by vertical movements. Regions on the downthrown side of a normal fault, for example, have an additional sub-surface load on them and subside. By way of contrast, regions on a fault's upthrown side have less load and so experience uplift. Studies of the 'footwall uplifts' that flank extensional rift systems (Vening Meinesz 1950; Weissel \& Karner 1989; King \& Ellis 1990; Gilchrist \& Summerfield 1990; Ebinger et al. 1991) suggest that the response of the lithosphere (which includes the crust) is not limited to the region where the load has been removed. Rather, it occurs over a much wider region. The extent of the deformation depends on the flexural rigidity of the lithosphere (or the equivalent elastic thickness) but, it may involve vertical movements of up to several tens of metres that extend over a horizontal distances of a few to several hundreds of kilometres.

If the lithosphere of south-central England has a high flexural strength then we would expect that the unloading of sediments from the Vales of Evesham and Gloucester would have affected not only the Vale floors but, also flanking regions. In particular, we would expect that the flanks of the Vales would have experienced a regional tectonic uplift. The Cotswolds are one such region. Others are the region west of the Malvern Line (including the Abberley Hills to the north and the Forest of Dean to the south) and the high ground around Birmingham, such as the Lickey Hills. Evidence for flexure would be the existence of a surface which tilts away from the region of the excavation and, more importantly, has a topographic slope which is not necessarily the same as the dip slope. 


\section{The topographic and dip slopes of north Oxfordshire}

One of the most striking features of the landscape of north Oxfordshire is the presence of a plateau surface which dips gently (about $0.3^{\circ}$ ) to the SE from an elevation of $215 \mathrm{~m}$ at Edge Hill to about $70 \mathrm{~m}$ at Oxford. The surface is preserved on the more resistant Jurassic strata which range in age from the Middle Lias (Pliensbachian) at Edge Hill in the NW to the Oxford Clay (Callovian and Oxfordian) along the upper reaches of the Thames river valley in the SE, where it terminates at the base of the Corallian escarpment (Fig. 2). The surface is incised by the major rivers and their tributaries and is therefore not continuous across the entire region.

The fact that older rocks progressively outcrop on the plateau surface to the NW suggests that the tilted surface is not a dip slope. This is confirmed by inspection of the geological cross-sections published on the British Geological Survey (BGS) 1:50 000 sheets 236 (Witney), 218 (Chipping Norton) and 201 (Banbury) which show clearly that older Jurassic beds outcrop on this topographic surface towards the NW.

To make this point clearer, we have constructed a perspective image of the topography and outcrop geology of the Chipping Norton region (Fig. 3). The height of the image is the topography derived from the Ordnance Survey DTM. The outcrop geology, which is based on a vector file constructed by the BGS, has been superimposed on the topography. The perspective is as it would appear to an observer who viewed the centre of the region from the north-east at an elevation above sea-level of $500 \mathrm{~m}$. The geology has been constructed entirely from outcrop data and therefore does not contain any subsurface information. It is clear from Fig. 3, however, that the slope of the plateau surface (about $0.3^{\circ}$ ) differs from that of dip slope (about $0.5^{\circ}$ ). The local irregularities in individual formation boundaries are likely to be caused by cambering (Hollingworth et al. 1944) of the more resistant blocks down the steeper topographic slopes. These deposits are termed 'head' by the BGS and were formed under peri-glacial conditions.

The Northern Drift gravel deposits that cover the tilted plateau surface are fluvial in origin and get progressively older to the north-west (see BGS 1:50000 sheets 236 and 218) suggesting perhaps that this surface was planed off gradually over a large part of Pleistocene time. The fact that the Northern Drift gravels now lie on older Jurassic rocks to the NW suggest that there has been tilting of the Jurassic prior to the deposition of the river gravels, so that not all the tilting was younger than $450 \mathrm{ka}$. However, most of the tilting of the north Oxfordshire plateau appears to be related to Late Pleistocene uplift. We infer, for example, from the Northern Drift Group that the entire region was at or close to sea level about $450 \mathrm{ka}$. Since this time, incision of the rivers of north Oxfordshire has clearly been related to uplift of the Cotswold and Edge Hill escarpments. This concept of repeated uplift events is in agreement with the conclusions of (Jones 1999a,b) for landscape evolution over other parts of SE England.

The NE-SW strike of the tilted surface of north Oxfordshire cannot be easily explained as a thermal or flexural bulge that formed as a consequence of extension in the generally northsouth trending Viking and Central grabens of the North Sea basin (Barton \& Wood 1984). Neither can it be accounted for by Late Cenozoic extension in the London and English Channel basins. Not only does the trend differ but, there is insufficient thickness of younger Cenozoic and Pleistocene sediments beneath these regions to have caused large amounts of subsidence and, hence, a flanking bulge. This is true, irrespective of whether the sediments are compensated by a weak or strong crust. The surface has a similar trend to the surface deformation predicted by a hypothetical mantle hotspot centred beneath the Irish Sea (Cope 1994), but the timing of the uplift that it causes (late Maastrichtian to late Palaeogene) does not fit our evidence for a Late Pleistocene age. The same timing argument can be applied to the hypothesis of Brodie \& White (1994) who suggest that the British Isles has been tilted up at its NW end by magmatic underplating associated with the opening of the North Atlantic Ocean.

We believe that the tilted surface of north Oxfordshire is a consequence of the excavation and, hence, unloading, of the soft Late Triassic and Early Jurassic clays and marls from the Vales of Evesham and Gloucester and adjacent low lying areas during the Late Pleistocene. In order to test whether the excavation of the Vales could cause the required amounts of uplift, we have constructed topography profiles of the north Oxfordshire tilted surface and compared them to the predictions of simple models of lithospheric flexure. The actual model we use is that of a thin elastic plate that overlies an inviscid fluid. Similar models have been widely used to model the deformation of the lithosphere due to long-term (i.e. $>1 \mathrm{Ma}$ ) loads. They have also been used to model short-term loads. Walcott (1970), for example, used an elastic plate model to model the rebound that followed the retreat of the last major ice advance onto the North America lithosphere, 10-15 ka. Recently, Watts \& Zhong (2000) have shown that the majority of the compensation of volcanic loads emplaced on old oceanic lithosphere is complete within about $10 \mathrm{ka}$.

Figure 4 shows the uplift that would be expected after the removal of a load from the surface of an elastic plate. The load is assumed to be two-dimensional and its width and thickness were chosen so as to resemble the geometry of the northern part of the Vales of Evesham and Gloucester. Clearly, both the width and relief of the Vale vary significantly. The Vale of Gloucester, for example, is narrower than the Vale of Evesham yet, the thickness of removed material appears greater. Values of the elastic thickness of the lithosphere, $T_{\mathrm{e}}$ (a measure of the strength of the lithosphere), of 5, 10, 15 and $50 \mathrm{~km}$ have been assumed in the calculations. The calculated profiles show a similar form which is characterized by a central uplift over the excavated region and a broad rim uplift in flanking regions.

Figure 5 compares observed topographic profiles of the plateau surface of north Oxfordshire to the predictions of the unloading model. Because of the heavy dissection of the surface by rivers, it is difficult to compare observed and calculated profiles directly. We have therefore compared the model predictions to an 'ensemble average' of seven equally spaced NW-SE trending profiles of the surface (Fig. 2). Ensemble averaging is a spectral technique which suppresses features that are present on only a few profiles while at the same time retains features that are common to all profiles. Thus, features such as river valleys which have been incised at different points and depths along each profile should be suppressed while 'common' features such as the tilted plateau surface, the Edge Hill escarpment and, any central uplifts of the excavated region will be enhanced. The figure shows good general agreement between the observed and calculated profiles. In particular, the amplitude and wavelength of the tilted surface in north Oxfordshire is well explained by a flexural uplift model with $T_{\mathrm{e}}=10 \mathrm{~km}$. Higher values of $T_{\mathrm{e}}$ would predict too broad an uplift while lower values would imply a too narrow one. 

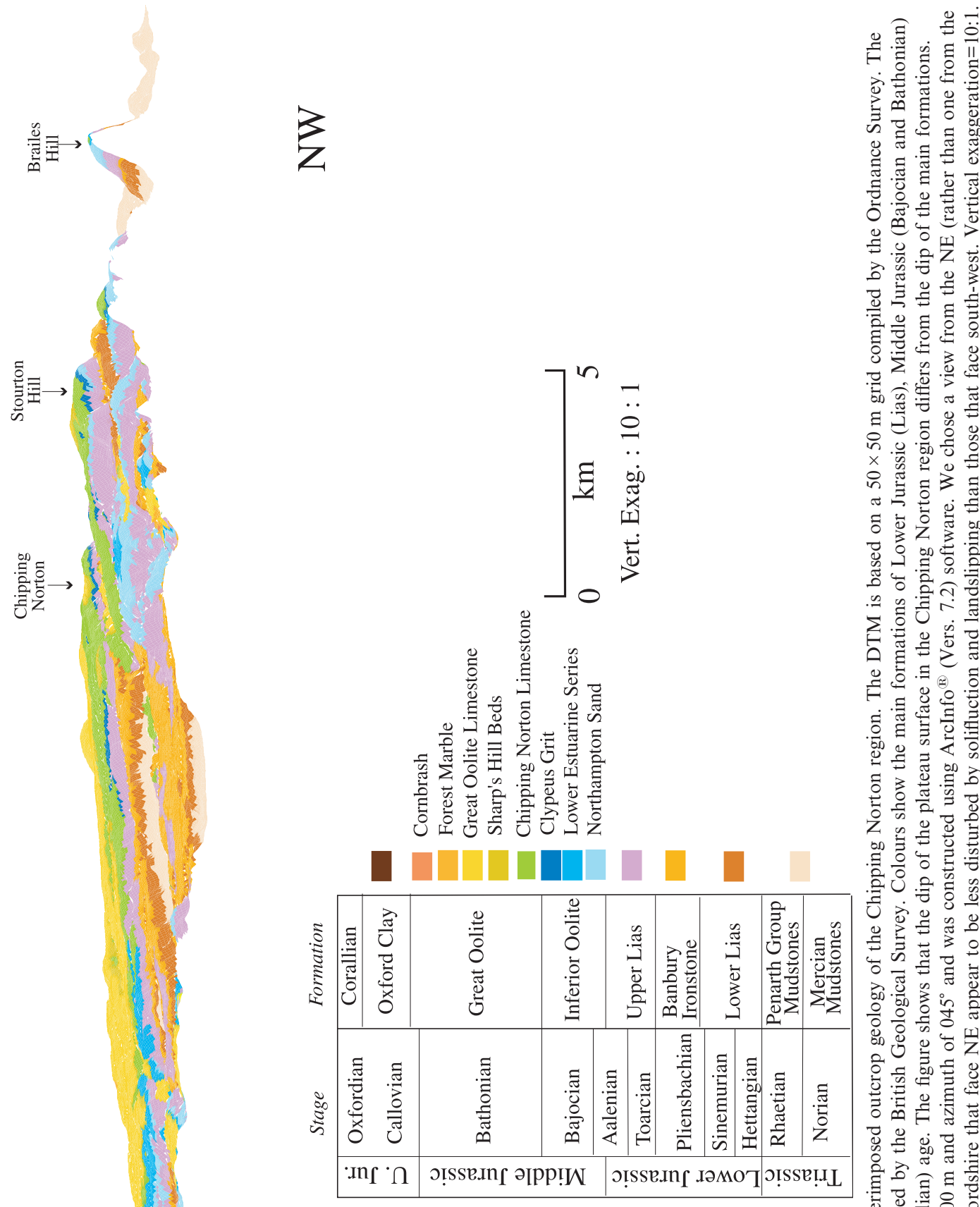

웡요

的成密

目过的

in 능

品

๙ 3 윰

ปี

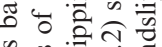

记

$\sum_{i}$

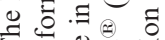

墕记

别

过

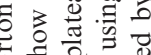

之证要

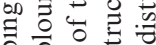

范 :

ठै

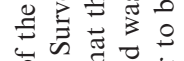

정

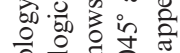

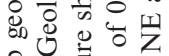

응

记

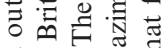

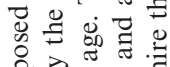

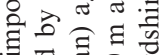

这.

के

30.

$\sum$ 政.

记

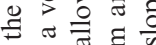

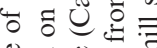

品

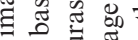

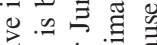

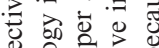

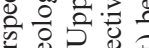

$\frac{I I}{2}$

齐品 $\geq$

m oㅇㅎㅎ

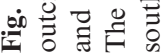




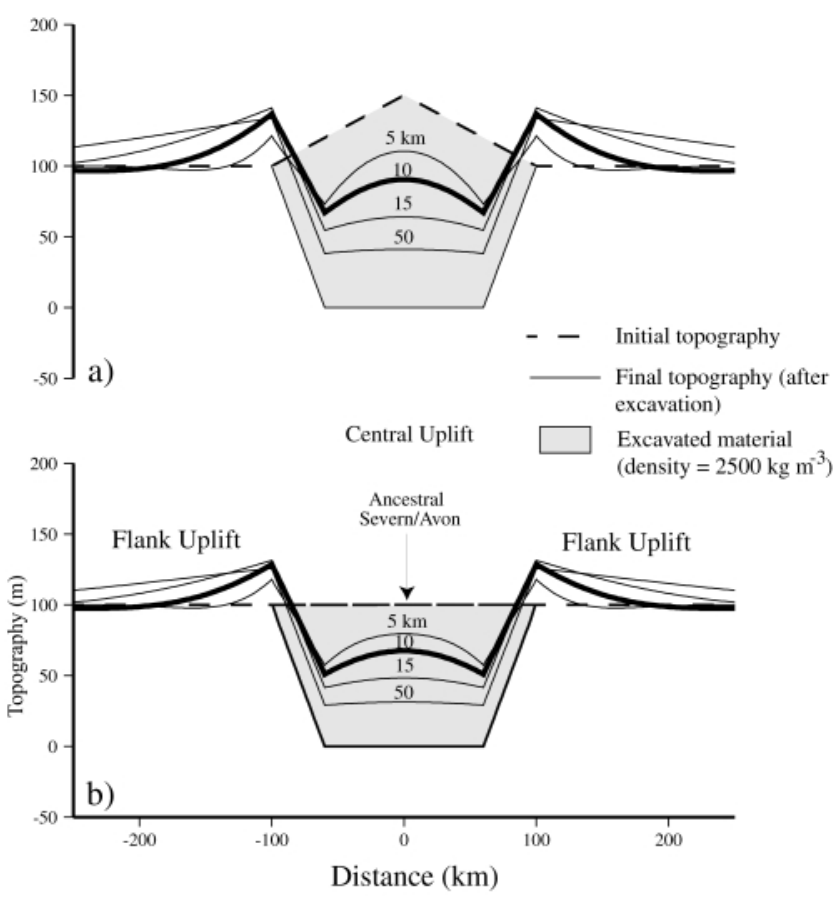

Fig. 4. Simple models of flexure due to the unloading of the lithosphere by sediment loads. The calculations (solid lines) assume 2-dimensionality, the excavated material (assumed density $=2500 \mathrm{~kg}$ $\mathrm{m}^{-3}$ ) is replaced by air (density $=0 \mathrm{~kg} \mathrm{~m}^{-3}$ ), a state of isostasy exists before and after unloading, there is no alteration of the thickness and density of the 'crust' that underlies the excavated material and overlies the mantle as a consequence of the unloading and, an elastic thickness of the lithosphere, $T_{\mathrm{e}}$ (which is determined by its flexural rigidity), of 5, 10 (heavy solid line), 15 and $50 \mathrm{~km}$. Other parameters assumed in the calculations are Young's Modulus $=100 \mathrm{GPa}$, Poisson ratio $=0.25$ and, gravitational acceleration $=9.81 \mathrm{~m} \mathrm{~s}^{-2}$. Two cases of topography prior to excavation are shown. Model (a) is based on $150 \mathrm{~m}$ high excavated region (grey-shades) and Model (b) on a $100 \mathrm{~m}$ high excavated region (grey-shades). Model (a) was chosen because the entire area of the present day Severn valley may not have been at a constant elevation.

A value for $T_{\mathrm{e}}$ of $10 \mathrm{~km}$ is low when compared to estimates from the continental cratonic interiors. However, it is within the range of values that have been determined from gravity and stratigraphic modelling of continental rifts. These values range from a low of 3-6 km for the Viking and Central grabens in the North Sea (Barton \& Wood 1984; Kusznir et al. 1991) to a high of $17-38 \mathrm{~km}$ for the East Africa Rift system (Ebinger et al. 1991). During the Jurassic, England was situated between the North Sea and the developing Atlantic Ocean basin (Ziegler 1988) and so the entire region was in extension. The crust that now underlies north Oxfordshire may therefore have been weakened during the extension and so we speculate that the low $T_{\mathrm{e}}$ value, required to explain the height and width of the Late Pleistocene tilted surface, has been inherited from a previous rifting event.

\section{Discussion}

While a model in which the excavation of the Vales of Evesham and Gloucester causes flexural unloading of a broad region of south-central England provides a simple and elegant

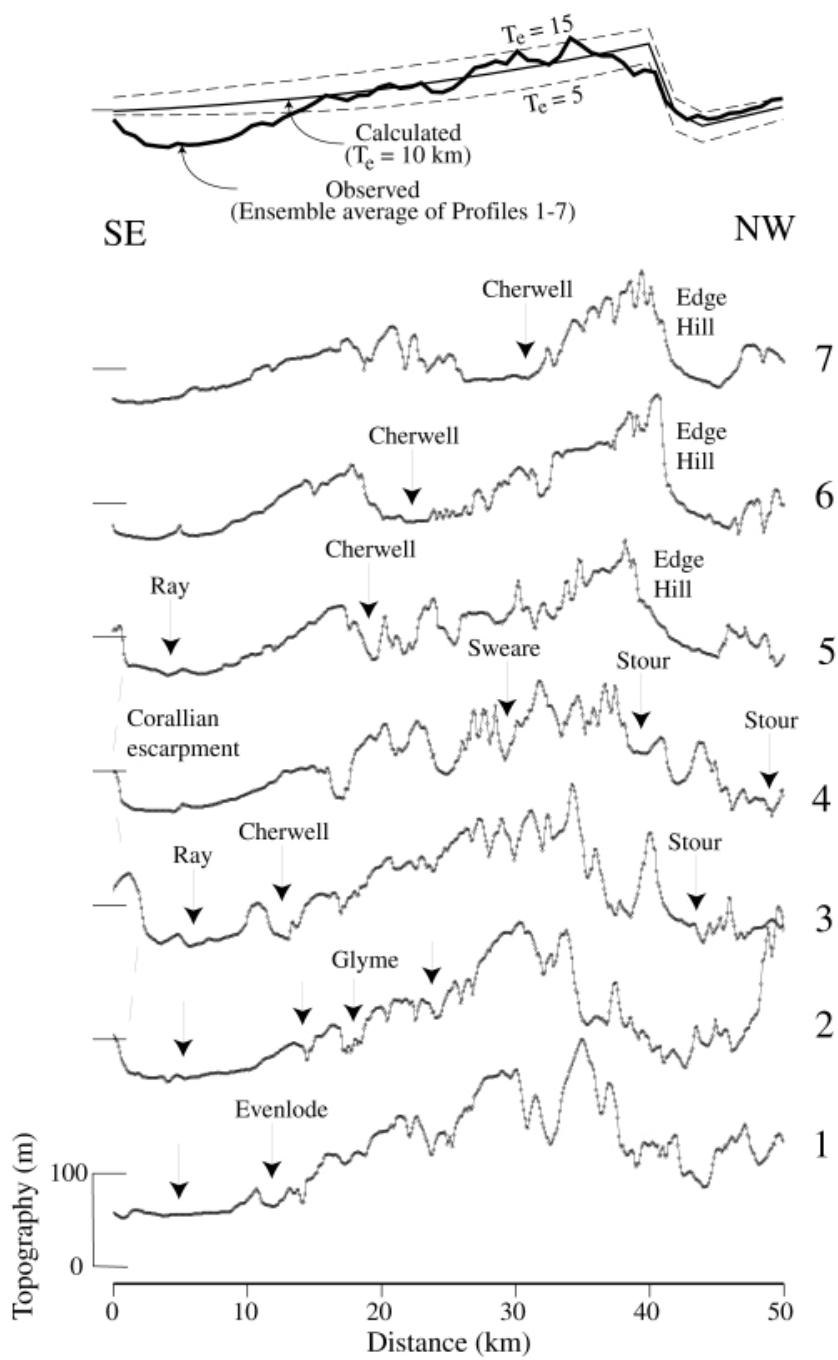

Fig. 5. Comparison of the calculated uplift due to flexural unloading to observations. The calculated profile (thin line) is based on the uplift model in Fig. $4 \mathrm{~b}$ and $T_{\mathrm{e}}=5$ and $15 \mathrm{~km}$ (dashed line) and $T_{\mathrm{e}}=10 \mathrm{~km}$ (solid line). Profiles 1 to 7 have been constructed by sampling the DTM in Fig. 1 along the profiles located in Fig. 2a. The observed profile (thick line) is based on an ensemble average of topography Profiles 1-7 (Fig. 2a). The vertical arrows indicate the location of the main rivers and tributaries along each profile. Also shown is the location of the Edge Hill escarpment. The ensemble average enhances the 'common' features of the topographic profiles such as the tilted plateau surface and the escarpment, while at the same time as suppressing the effects of the dissection of the plateau by the main rivers and tributaries.

explanation for the tilted plateau surface of north Oxfordshire, there are complications.

First, the Northern Drift Group, was not deposited on a flat surface. The fact that the deposits are found on older Jurassic rocks to the NW indicates that these rocks were gently tilted prior to the Pleistocene. Possible mechanisms for such tilting are hot-spot activity (Cope 1994) and igneous underplating (Brodie \& White 1994) during the Palaeogene. Subsequent to the Palaeogene, however, there must have been a long period of crustal stability. The quartzite pebbles in Oxfordshire indicate fast flowing rivers transporting quartzite pebbles from the Birmingham area across the outcrop of Late Triassic and 
Early Jurassic clays and marls prior to $450 \mathrm{ka}$. Therefore, south-central England cannot have been uplifted prior to this time. Otherwise the rivers would have been diverted down the outcrop of the soft sediments. Thus, while regional prePleistocene movements may have contributed to some of the uplift of the Cotswold and Edge Hill escarpments, most of the uplift occurred following deposition of the Northern Drift deposits, between $450 \mathrm{ka}$ and the present day.

Another possible explanation for the tilting is the waxing and waning of ice sheet loads. For example, we know that during the past approximately $2 \mathrm{Ma}$ ice may have covered at least part of the Vales of Evesham and Gloucester region. Following withdrawal of the ice to the main load 'centres' in Wales and Scotland, the region that was loaded would have been uplifted while flanking regions would have subsided. Therefore, there may have been some large-scale tilting of the Mesozoic and younger Cenozoic strata of south-central England in the Early Pleistocene but, again, the uplift must have been prior to the deposition of the Northern Drift.

Secondly, while we have discussed how the re-charging of river systems and underlying lithology may have been important factors in explaining why so much material was excavated from the Vales of Evesham and Gloucester, we have not addressed the question of the triggering mechanism. The Malvern Line, which forms the western boundary of the Vales appears to have been fixed with time. In contrast, the Cotswold escarpment has retreated to the SE leaving a number of outliers in its 'wake'. This escarpment has formed since $450 \mathrm{ka}$ at a time when the Late Triassic and Early Jurassic soft clays and marls of the Vales of Evesham and Gloucester were being incised and their flanks were being uplifted by flexure. One problem is the question of how the resistant Middle and Upper Jurassic limestones, that once extended to the NW of the Cotswold Hills, were initially breached. Regional tilting, together with changes in the stress state, due to the waxing and waning of ice sheets may have been sufficient to fracture the resistant surface rocks and expose the softer rocks below. Unfortunately, uncertainties in ice loading history and the rheology of the central England lithosphere preclude a quantitative estimate of these effects.

Despite these complications, we believe that flexural uplift following excavation of large volumes of Mesozoic sediments from the Vales of Evesham and Gloucester is likely to be the main cause of both the escarpments and the tilted plateau surface that we see at the present day in north Oxfordshire. The existence of such a surface has a number of implications. First, flexural uplift provides a simple explanation for the dissection of the Cotswold Hills and, possibly, Herefordshire to the west of the Malvern line (Maddy 1997) by the main rivers and tributaries. Secondly, it shows that even in what is now a topographically subdued region, far away from active plate boundaries, tectonics, in the form of lithospheric flexure, may have a profound impact on landscape development.

\section{Conclusions}

(1) The Northern Drift lies on progressively older rocks towards the NW of Oxfordshire suggesting that the Jurassic beds of the Cotswold and Edge Hill escarpments were slightly tilted prior to the deposition of any Pleistocene gravels.

(2) Quartz clasts up to $20 \mathrm{~cm}$ diameter were transported from Birmingham to Oxford in the Northern Drift prior to $450 \mathrm{ka}$. Therefore, the entire south Midlands regions was of low relief at this time.
(3) The Cotswolds and north Oxfordshire is dominated by a tilted plateau which is inclined about $0.3^{\circ}$ to the SE. This contrasts with the approximately $0.5^{\circ} \mathrm{dip}$ of the underlying Jurassic beds. The plateau surface is therefore not a dip slope.

(4) Assuming that the youngest beds in the Northern Drift are around $450 \mathrm{ka}$, this was the time of a major change in the river systems of south-central England. Prior to $450 \mathrm{ka}$, a river flowed from Birmingham to Oxfordshire and hence into the Thames basin. Subsequent to this time, the flow from Birmingham was diverted along the line of the present Severn (the outcrop of the Lower Jurassic clays), eventually reaching the Celtic Deep, west of the present day Bristol channel. The age of this change in river flow coincides with (a) the onset of Pleistocene sedimentation in the Celtic Deep and (b) the onset of erosion of Middle Jurassic limestones in the Cotswolds of north Oxfordshire.

(5) The re-direction of the river flow caused large volumes $\left(>500 \mathrm{~km}^{3}\right)$ of soft Late Triassic and Early Jurassic clays and marls to be excavated from the Vales of Evesham and Gloucester.

(6) The escarpments and tilted plateau surface in north Oxfordshire are attributed to scarp retreat and flexural unloading following this excavation. Comparisons between observed and calculated topography profiles that the elastic thickness of the lithosphere beneath north Oxfordshire is about $10 \mathrm{~km}$. We speculate that the low value has been inherited from a previous rifting event.

We are grateful to the Digimap Project at the University of Edinburgh for provision of the Ordnance Survey topographic data and the British Geological Survey at Keyworth who provided the data used to construct Figs 1-3 and 5. M. Badley, M. Ellis, D. Gardner and $\mathrm{N}$. White provided helpful comments on earlier versions of the manuscript.

\section{References}

Arkell, W.J. 1947. The geology of Oxford. Oxford University Press.

Audley-Charles, M.G. 1970. The Triassic Paleogeography of the British Isles. Quarterly Journal of the Geological Society, London, 126, 49-89.

Barton, P.J. \& Wood, R.J. 1984. Tectonic evolution of the North Sea basin: Crustal stretching and subsidence. Geophysical Journal of the Royal Astronomical Society, 79, 987-1022.

Bowen, D.Q., Rose, J. \& McCABe, A.M. 1987. Correlation of Quaternary glaciations in England, Ireland, Scotland and Wales. Quaternary Science Reviews, 5, 299-340.

Bridgland, D.R. 1994. Quaternary of the Thames. Chapman \& Hall, London.

Brodie, J. \& White, N. 1994. Sedimentary basin inversion caused by igneous underplating: Northwest European continental shelf. Geology, 22, 147-150.

Buckland, W. 1823. Reliquiae Diluvianae. John Murray, London.

Cocks, L.R.M. 1993. Triassic pebbles, derived fossils, and the Ordovician to Devonian paleogeography of Europe. Journal of the Geological Society, London, 150, 219-226.

Cope, J.C.W. 1994. A latest Cretaceous hotspot and the southeasterly tilt of Britain. Journal of the Geological Society, London, 151, 905-908.

Ebinger, C.J., Karner, G.D. \& Weissel, J.K. 1991. Mechanical strength of extended continental lithosphere: Constraints from the western rift system. Tectonics, 10, 1239-1256.

Edmonds, E.A., Poole, E.G. \& Wilson, V. 1965. Geology of the country around Banbury and Edge Hill. British Geological Survey Memoir Sheet 201.

GibBard, P.L. 1999. The Thames Valley, its tributary, valleys and their former courses. In: Bowen, D.Q. (ed.) A revised correlation of Quaternary deposits in the British Isles. Geological Society, London, Special Reports, 24, 45-58.

Gilchrist, A.R. \& Summerfield, M.A. 1990. Differential denudation and flexural isostasy in formation of rifted-margin upwarps. Nature, 346, 739-742.

Graham, C.C. \& Straw, A. 1988. Quaternary. In: Cope, J.C.W., Ingham, J.K. \& Rawson, P.F. (eds) Atlas of Paleogeography and Lithofacies. Geological Society, London, Memoirs, 13, 149-153. 
Hey, R.W. 1986. A re-examination of the Northern Drift of Oxfordshire Proceedings of the Geologists' Association, 97, 291-301.

Hollingworth, S.E., Taylor, J.H. \& Kellaway, G.A. 1944. Large-scale Superficial Structures in the Northampton Ironstone Field. Quarterly Journal of the Geological Society, London, 100, 1-44.

JoNES, D.K.C. 1999a. Evolving models of the Tertiary evolutionary geomorphology of southern England, with special reference to the Chalklands. In: Smith, B.J., Whalley, W.B. \& Warke, P.A. (eds) Uplift, Erosion and Stability: Perspectives on Long-term Landscape Development. Geological Society, London, Special Publications, 162, 1-23.

1999b. On the uplift and denudation of the Weald. In: Smith, B.J., Whalley, W.B. \& Warke, P.A. (eds) Uplift, Erosion and Stability: Perspectives on Long-term Landscape Development. Geological Society, London, Special Publications, 162, 25-43.

KING, G. \& ElLis, M. 1990. The origin of large local uplift in extensional regions. Nature, 348, 689-693.

Kusznir, N.J., Marsden, G. \& Egan, S.S. 1991. A flexural-cantilever simpleshear/pure shear model of continental lithosphere extension: Applications to the Jeanne d'Arc basin, Grand Banks and Viking Graben, North Sea. In: Roberts, A.M., Yielding, G. \& Freeman, B. (eds) The Geometry of Normal Faults. Geological Society, London, Special Publications, 56, 41-60.

MADDY, D. 1997. Uplift-driven valley incision and river terrace formation in southern England. Journal of Quarterly Science, 12, 539-545.
Tappin, D.R., Chadwick, R.A., Jackson, A.A., Wingfield, R.T.R. \& Smith, N.J.P. 1994. The geology of Cardigan Bay and the Bristol Channel. British Geological Survey, London.

Vening Meinesz, F.A. 1950. Les graben africains, résultat de compression ou de tension dans la croute terrestre? Institut royal colonial belge, Bulletin, 21, $539-552$.

WALCOTT, R.I. 1970. Isostatic response to loading of the crust in Canada. Canadian Journal of Earth Science, 7, 716-727.

Warrington, G., Audley-Charles, M.G., Elliot, M.G., Evans, R.E., Imley-Cook, W.B., Kent, H.C., Robinson, P.E., Shotton, P.L., Shotton, F.W. \& TAYLOR, F.M. 1980. A correlation of the Triassic rocks of the British Isles. Geological Society, London, Special Report, 13.

WATts, A.B. \& Zhong, S. 2000. Observations of flexure and the rheology of oceanic lithosphere. Geophysics Journal International, In press.

Weissel, J.K. \& Karner, G.D. 1989. Flexural uplift of rift flanks due to mechanical unloading of the lithosphere during extension. Journal of Geophysical Research, 94, 13,919-13,950.

Whiteman, C.A. \& Rose, J. 1992. Thames river sediments of the British Early and Middle Pleistocene. Ouaternary Science Reviews, 11, 363-375.

ZIEGLER, P.A. 1988. Evolution of the Arctic-North Atlantic and the western Tethys. American Association of Petroleum Geolists, Memoir, 43.

Received 7 December 1999; revised typescript accepted 17 March 2000.

Scientific editing by Alex Maltman. 